\title{
Oscillatory Flow Mixer for Pulp Bleaching
}

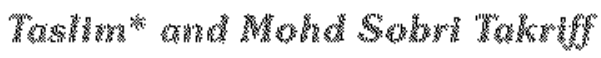 \\ Departwert of Chemical and Process Engheerimg, \\ Universiti Kebangsaan Makaysia,

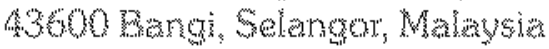

\begin{abstract}
This paper reports the results of an investigation on the use of oscillatary

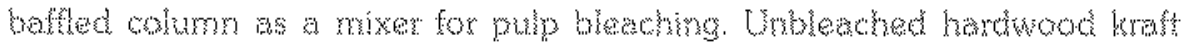

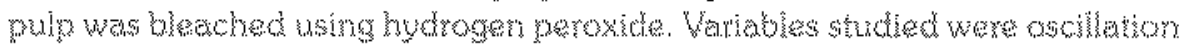

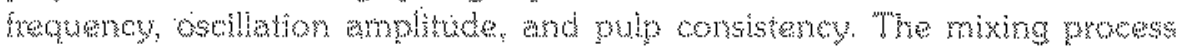

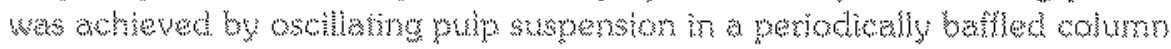

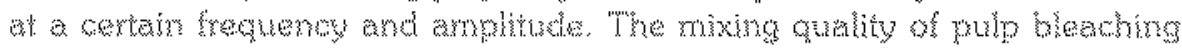

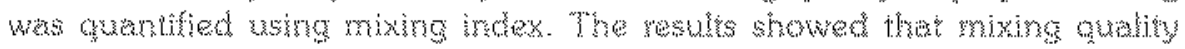

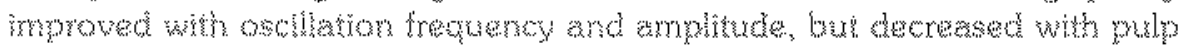
consustency This whical device is very promising as a mixar for pulp bienciring.
\end{abstract}

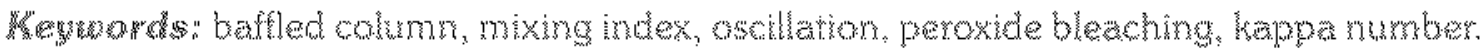

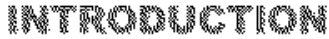

Mixing of chemicals ant pulp ns one of the rust

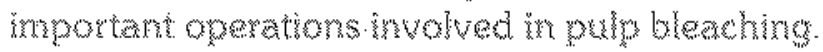

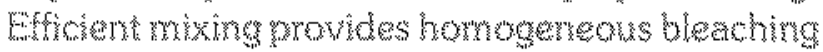

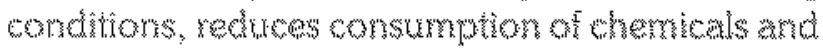
exergy, improves prodict oud hity, and reduces the enviromental bou. When mixing is notunifom, some region of the pulp receve chemingls in exwss of those reguired, some of which is consumed in less desirable sids reaction. Other tegrons reckive

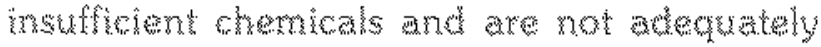
wteached. The net effect is that additional chemicat is recured to obtain a destred degree of blecthing. and putp of less thax optimal strength is prowuced (Torregrossa, 1983). Varous types of mixers have been used over the years to acheve these bjectives such as stred tanks and stutc mixers.

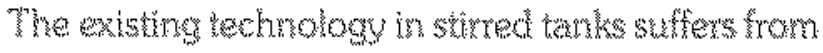

pulp dewrataton or damage by the shearing

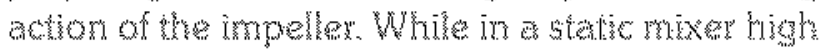

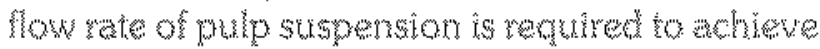
good mixing, which mples high energy consumption. Osculletory batfed columns have been reported in numerous publicturions as a very promissing way to improve mixing in columns (hewgill et al, 1993, Mekley, 1987, w99). "The radial velocity component is comparable to the axal velocty componem anhancing mixhg in

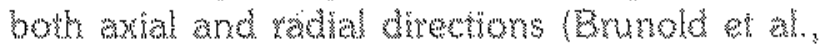
1989. Dickens, 1989).

The use of oscilatory bafled columps as

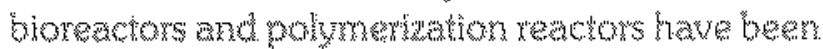
studied by weveril researchers (Hawson and

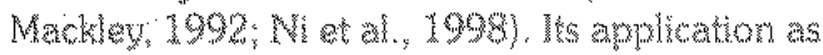
a mixer for pulp blewhing has not been investigated whit mow meretore, whe objectives of thes paper were to study the potential of baftert

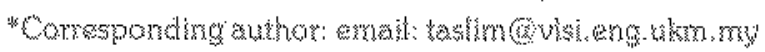


column combined with osuntatery How as anker

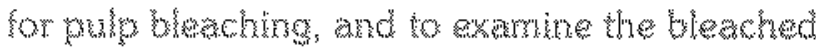
pulpo wudity.

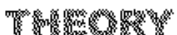

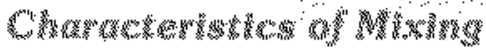

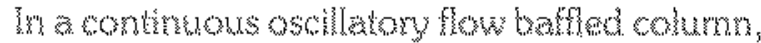

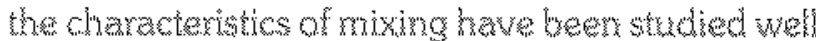
from the resulenes time distribution (RTD) pernecture, i.e. Whe changes of tracer concentraton are measured as a function of ume as the mixng takes plece im such system, and a singie warameter known as the axial divpersion copffichent, was evaluated from WT curves. Then, this coeffiment

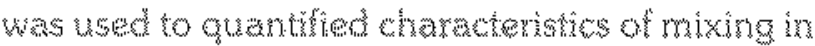
the system (Dickens et al, 1989; Howes and Machlay, 1990 .

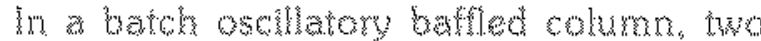

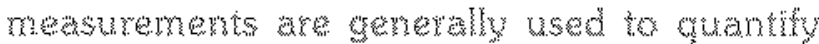
ming characteristics, mandy, the mixtug the reguled to create a predermined level of

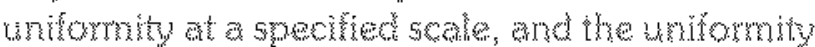

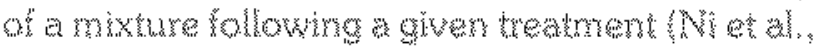

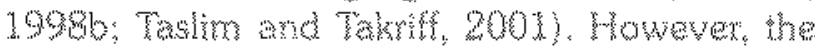
uniformity of a mixture following o given tratment

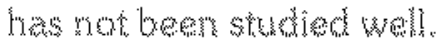

ha bathoperated mixems sulp bigating

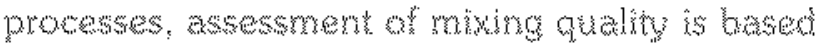

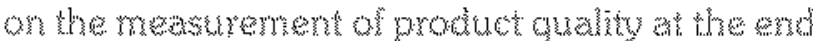
of the process suck as rasidu d chemical ontent

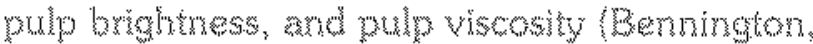

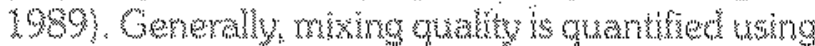

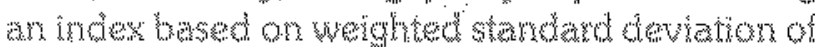

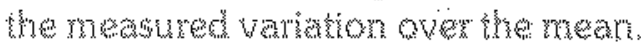

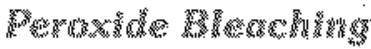

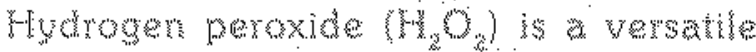
Wlawhing agent that has beer appled to weaching

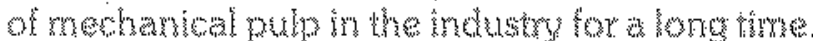
Recently under the presurwe to decrease the use

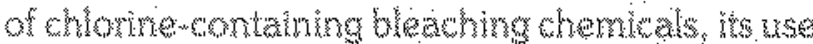

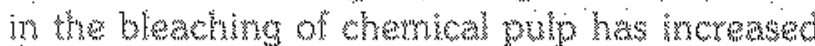
wigniticantly. Bleaching is done to increase the brightress of the pulp by ramoving residual lignumidal and other coloweontaining impurities. For

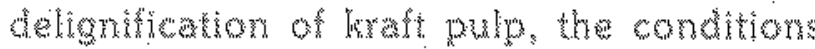

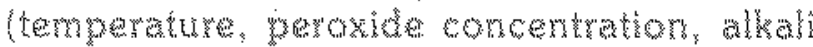
concentration) are usubly much harher than in peroxide brighening of mechandeal pulpos, so that lignin removal becomes wassible. Also, the natwe

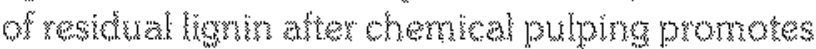
delignilication by several hydrogen perowide reachom mechankms, whe notive lignin in

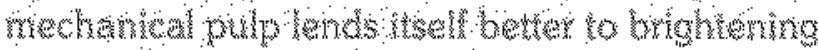
reactons (1,acheral, 1996, cherrer, 1997 Anderson and Armin, 1996 ). The degree of veacion which tukes place depends on the nature and the amoun of honin in the pulp, and on the rake of peroxide comportum.

"The conten of hym mus be tracked during

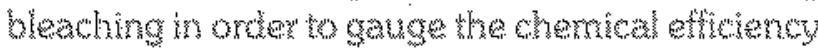
of the bleaching process. The residual lignim wan be detemined from the keppa number test by the

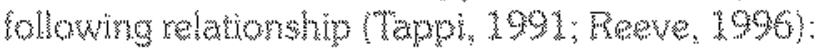

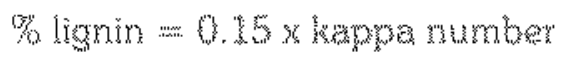

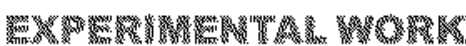

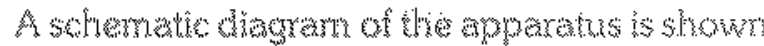
in Figure 1. The experiments were conducted in a

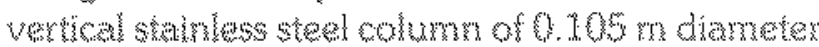

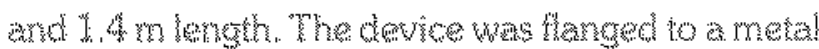

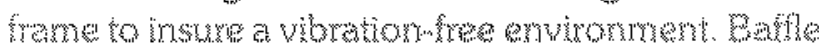

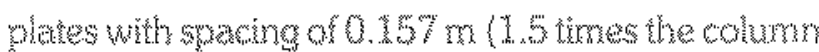
intenal dianeter) in between wates supported by

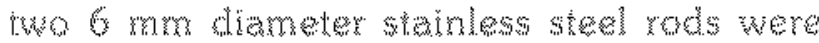

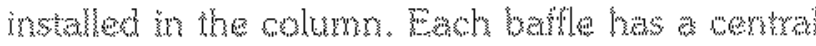

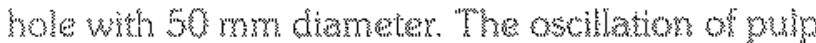
suppersion was achever by oscillating the bafle

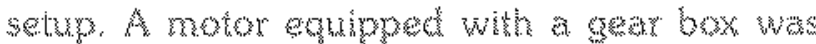

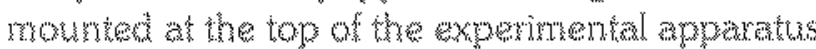

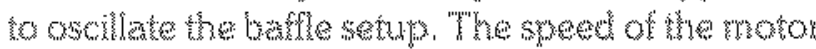
was controllo by a variable speed contwoler to provide oscilldon frewuencies in the range of 0.5 to $2,5 \mathrm{H}$. Oscilmetrom ampliqude can be varied by

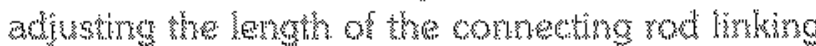
the beffe setug and the driver unit. Dewals of the

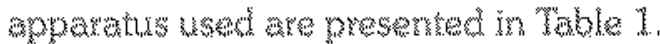

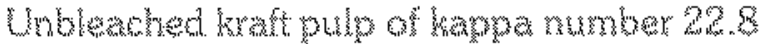

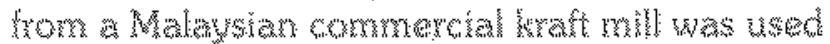

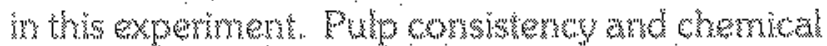
reagens a certain concertretrons were prepared as shown in Table 2 and inkodwed into the wixer. All concertrations are expresser in weidet percent per overndry weight of yutp. The pulp suspersion

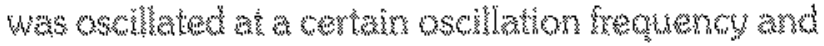

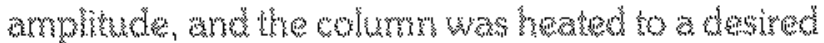
temperature. At she and of the experiment, he 
content of tye colunn wes quickly discharged noto cold watew al room temperature. The pulp shury wes then fittered and wathed conpletely. The

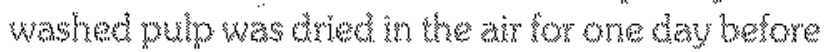
testing. The kappa number test was conducted

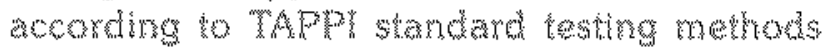
(Tapps. 2991 ).

In this study, mixho guality was guantifed using the mining index, M, whot is wmply the

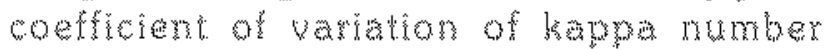
distribution, giver by the following equation:

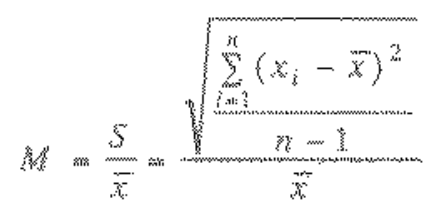

where $x$ is the measurect kappon number of the sample, $\mathrm{x}$ is men, and 5 the standard

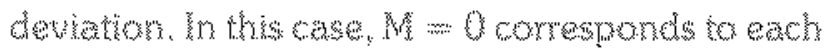
fiber receiving the samas mantity of bleachng argents.

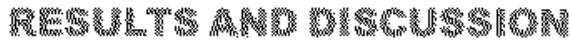

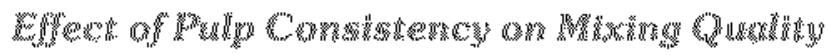

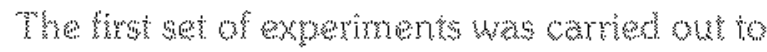
detemine the effert of pulp corsinsency on the

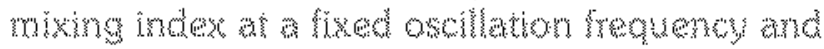

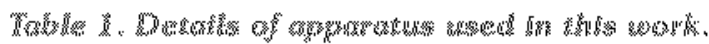

\begin{tabular}{|c|c|}
\hline 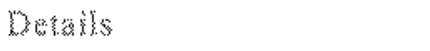 & Vialut \\
\hline 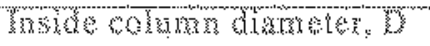 & $1,165 \mathrm{mon}$ \\
\hline 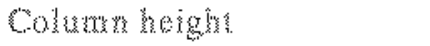 & 1.46010 \\
\hline 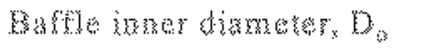 & $0.050 \mathrm{~m}$ \\
\hline 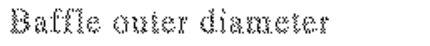 & $0.09{ }^{\prime \prime}$ \\
\hline 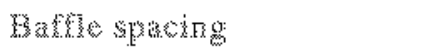 & 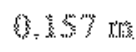 \\
\hline brote thickorsess & $0.002 \mathrm{nz}$ \\
\hline 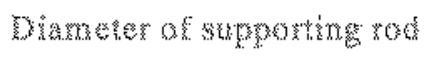 & $0.0460 \mathrm{dr}$ \\
\hline Number of bathes & 8 \\
\hline
\end{tabular}

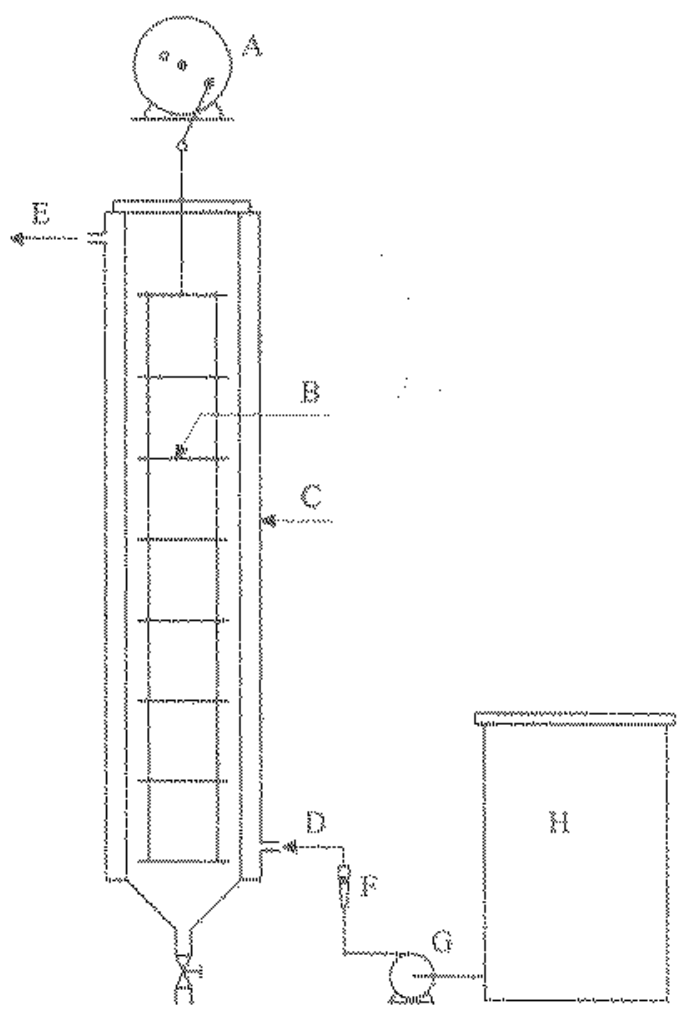

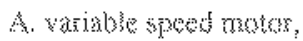

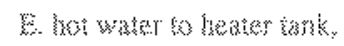

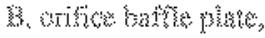
whow weter
o. jack â.

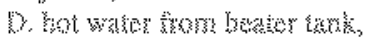

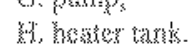

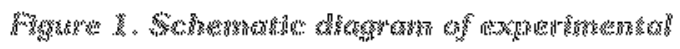

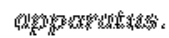

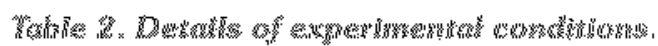

\begin{tabular}{|c|c|}
\hline batas & Whange \\
\hline 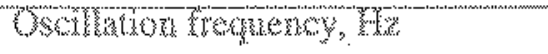 & 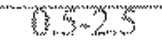 \\
\hline 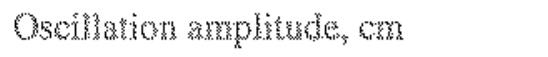 & $3.75,0.50$ \\
\hline 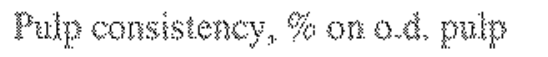 & 30.1010 \\
\hline 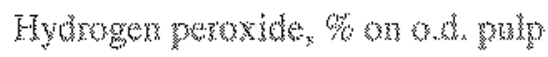 & 3 \\
\hline 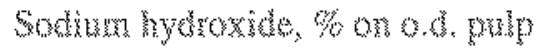 & 3 \\
\hline 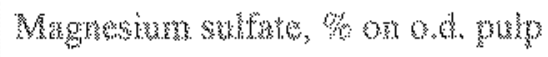 & a. \\
\hline 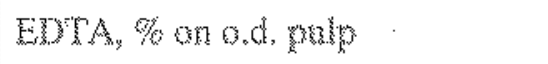 & 0.2 \\
\hline Blesching tim, gnimp & 60,120 \\
\hline Termperaturas. & 60 \\
\hline
\end{tabular}


andindude. The experinents were concucred for a range of pult consistercies at constant temperature and intital chement concentrations. The efrect of pulp consistency on kappa number show in Figure 2. "his howe shows that the kapa number cistributon wilen with pulp consisterey. The basie mechanism of mixing is to induce physical motion of the ingresterys. in the work, the movement of pulp suspension is produced by the action of oscitiation. As low puly consisturey (30), putp

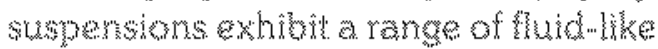
behavion, spreading from the motion of flock (hber networks) relatrve to one another through the motion of individual fbers to one anoher. Vortax formetions due to the interacton of pulp suspensing and bathles are mone pronounced under this condision. Suspension with higher consistencies (5-7\%) changes the mixing medumism and rabes the intentivy of vorex homed in the colum. The vom formation is disupted by ther nesworks. Pulp suppensions are actudly

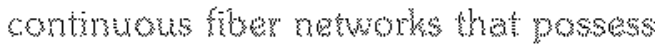
strunture and strength resulting from interaction beween neighoring bibers. Netwonk strength varies depending on

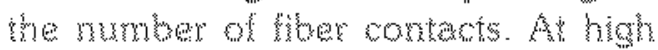
putp consistancy $(10 \%)$, the strencth

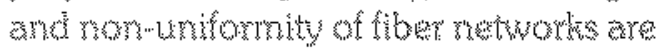
Whither meressed. As the comsistency of ine suspension increases, the number of hber /new interaction increases, and

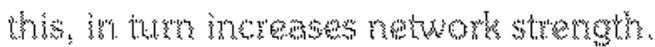
Jnher this condition, the task of mingm becones more difficult, which leads to a wider distribution of kappa mumber observed, resukng in higher rixing indices as showm in hate 3 .

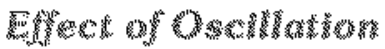

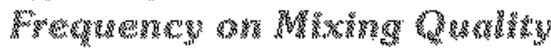

The second set of experments was conducted

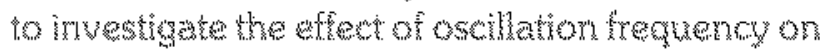
mixing index at a fixed oscillation arrolitude, constant ternperature and indul cheminal

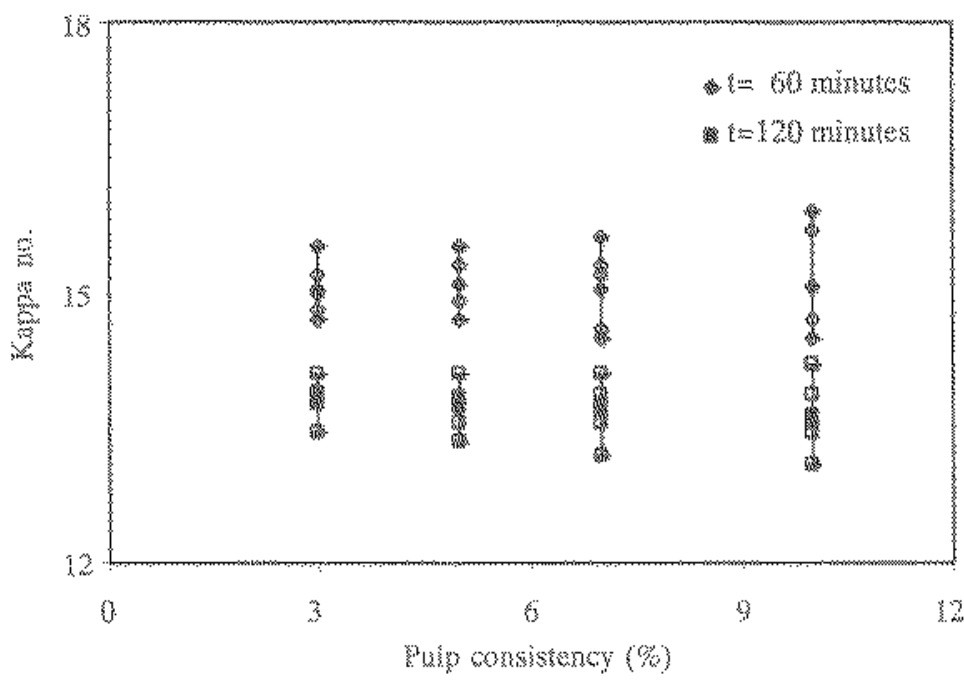

Fing

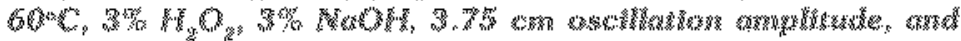

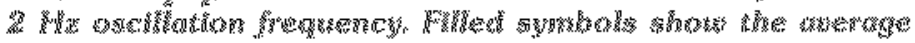

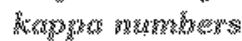

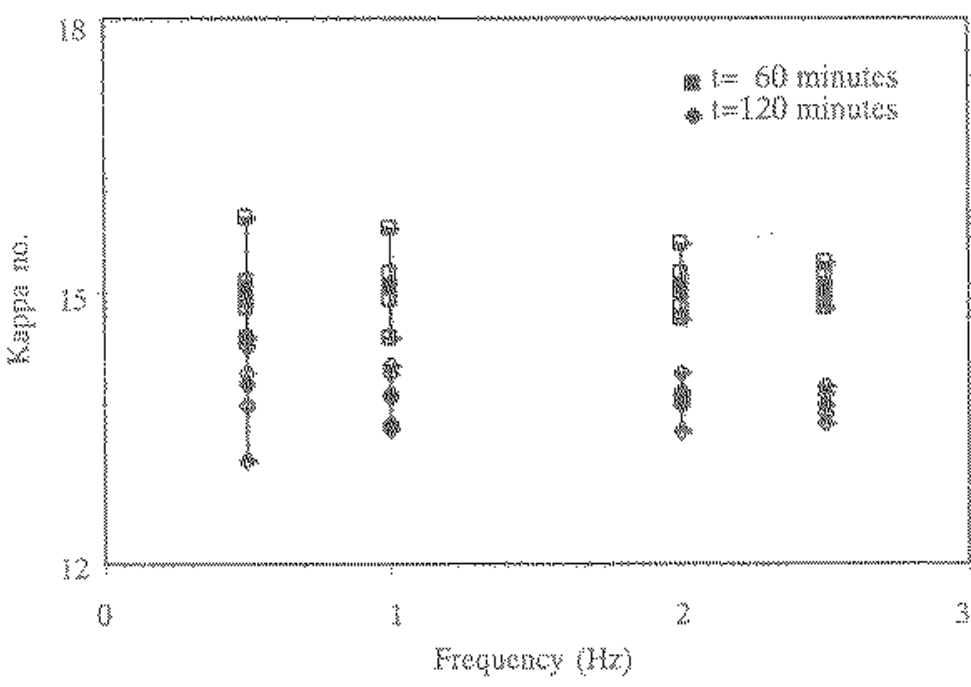

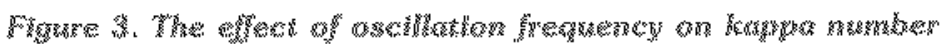

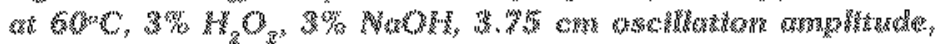

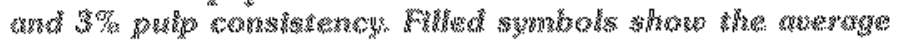

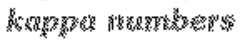

concentrations. As a lower range of oschination mequency being applied to pute suspension. mixing occurs at the zone between flock As As be intensity of osciliation is increased, the relatwe motion beween locks ncreases and flocks themselves are destroved. This phenomenon substantaly accelerated by he increase in

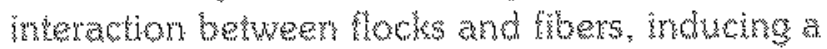
uriform mixing. Figue 3 show kappa number agatingt oscilution freguency. If can be seen that the mixing cualuty ingroves with oscillation 
frequency. More intense motions between flocks are formed at higher frequencies, giving better mixing and consequently a narrow distribution of kappa number is obtained. This is also shown in Table 3; the mixing indices decrease with increasing oscillation frequency. In addition, lower mixing indices reflect better mixing. For example at pulp consistency of $3 \%$ and 60 minutes, the mixing index at $2.5 \mathrm{~Hz}$ is half of that at $2.0 \mathrm{~Hz}$. Table 3 also shows the mixing efficiency as judged by the mixing index decreases with pulp consistency. The mixing index which at $10 \%$ pulp consistency is 5 times of that at $3 \%$ and 3.5 times of that at $5 \%$. In bleaching operations, good mixing is normally achieved at $M \leq 0.1$ (Bennington, 1996; Backlund et al., 1989).

\section{Effect of Oscillation \\ Amplitude on Mixing Quality}

Further experiments were performed by selecting different oscillation amplitudes at a fixed

Table 3. Mbxing quality of oscillatory flow mbxer.

\begin{tabular}{|ccccccc|}
\hline $\begin{array}{c}\text { Time } \\
(\text { min. })\end{array}$ & $\begin{array}{c}\text { Pulp } \\
\text { consistency } \\
(\%)\end{array}$ & $\begin{array}{c}\text { Frequency } \\
(\mathrm{Hz})\end{array}$ & $\begin{array}{c}\text { Amplitude } \\
(\mathrm{cm})\end{array}$ & $\overline{\mathrm{x}}$ & $\mathrm{S}$ & $\begin{array}{c}\text { Mixing } \\
\text { index } \\
(\mathrm{M})\end{array}$ \\
\hline 60 & 3 & 0.5 & 3.75 & 15.02 & 0.4868 & 0.0234 \\
60 & 3 & 1.0 & 3.75 & 15.04 & 0.4442 & 0.0295 \\
60 & 3 & 2.0 & 3.75 & 15.04 & 0.3209 & 0.0213 \\
60 & 3 & 2.5 & 3.75 & 15.02 & 0.2168 & 0.0172 \\
60 & 3 & 2.0 & 5.00 & 15.02 & 0.1301 & 0.0087 \\
60 & 5 & 2.0 & 3.75 & 15.08 & 0.3162 & 0.0119 \\
60 & 7 & 2.0 & 3.75 & 15.10 & 0.4712 & 0.0314 \\
60 & 10 & 2.0 & 3.75 & 15.06 & 0.6841 & 0.0454 \\
120 & 3 & 0.5 & 3.75 & 13.98 & 0.5474 & 0.0391 \\
120 & 3 & 1.0 & 3.75 & 13.90 & 0.3152 & 0.0228 \\
120 & 3 & 2.0 & 3.75 & 13.81 & 0.2381 & 0.0172 \\
120 & 3 & 2.5 & 3.75 & 13.76 & 0.1581 & 0.0115 \\
120 & 3 & 2.0 & 5.00 & 13.72 & 0.1170 & 0.0086 \\
120 & 5 & 2.0 & 3.75 & 13.73 & 0.2870 & 0.0209 \\
120 & 7 & 2.0 & 3.75 & 13.70 & 0.3386 & 0.0247 \\
120 & 10 & 2.0 & 3.75 & 13.63 & 0.4171 & 0.0306 \\
\hline & & & & & & \\
\hline
\end{tabular}


oscillation frequency. These runs were also carried out at constant temperature and initial chemical concentrations. Figure 4 plots kappa number versus oscillation amplitude obtained for two different amplitudes. This figure shows the distribution of kappa number decreases with oscillation amplitude. At higher oscillation amplitude, the flock motions are displaced further at each stroke, inducing rupture in the flocks. The interaction of pulp suspensions and baffles also becomes more significant, thus enhancement in mixing. As a result, narrower distribution of kappa number was achieved. Hence, lower mixing indices are obtained at higher oscillation amplitude.

Results obtained in this work indicate that oscillation frequency and amplitude are the main variables which control mixing efficiency. A combination of these two variables must be selected carefully to achieve optimal mixing. The pulp consistency appears to be the limiting variable in this device. Higher pulp consistency produces a network of fiber with greater strength. Mixing in oscillatory flow in a baffled column is achieved from the vortex formation due to the interaction between oscillating pulp suspension and the baffles. The fiber networks may disrupt vortex formation and dampen its intensity, this reduces mixing efficiency in the column. The results of this study also indicate that oscillatory baffled column has excellent potential for application in the pulp and paper industry. Further research however is required to determine the optimal conditions for application of this device in the pulp and paper industry.

\section{CONCLUSION}

The findings of this study indicate that an oscillatory baffled column is very promising as a mixer for pulp bleaching to improve mixing quality. The oscillation amplitude and frequency appear to be the controlling parameters which dictate the mixing efficiency in the oscillatory flow pulp bleaching column. The mixing quality increases with oscillation frequency and amplitude. However, the pulp consistency limits the mixing efficiency. Mixing quality decreases with pulp consistency at constant oscillation frequency and amplitude.

\section{NOTATIONS}

$M \quad$ Mixing index

$\mathrm{n} \quad$ Number of sample

S Standard deviation

$x_{1} \quad$ Kappa number of $i^{\text {th }}$ sample

$\bar{x} \quad$ Arithmetic mean of all measured kappa number

\section{ACKNOWLEDGEMENT}

The authors would like to thank the Ministry of Science, Technology and Environment of Malaysia for the funding of this work.

\section{REFERENCES}

Anderson, J.R., and Amini, B., Hydrogen Peroxide Bleaching, In Pulp Bleaching Principles 
and Practice, Dence, C.W. and Reeve, D.W., Eds., Tappi Press, Atlanta , 1996, 411-442.

Bennington, C.P.J., Kerekes, R.J., and Grace, J.R., Mixing in Pulp Bleaching, J. Pulp Paper Sci., 1989, Vol. 15 No.5, J186-J195.

Bennington, C.P.J., Mixing and Mixers, In Pulp Bleaching Principles and Practice, Dence, C.W. and Reeve, D.W., Eds., Tappi Press, Atlanta, 1996, 537-566.

Blacklund, B., and Parming, A.M., Effects of Inhomogeneities in Bleaching Studied by Mathematical Simulation, Nordic Pulp Paper Res. J., Vol. 2, 1987, 76-82.

Brunold, C.R., J.C.B. Hunn, Mackley, M.R. and Thomson, J.W., Experimental Observations on Flow Patterns and Energy Looses for Oscillatory Flow in Ducts Containing Sharp Edges, Chem. Eng. Sci., Vol. 44 No. 5, 1989, 1227-1244.

Dickens, A.W., Mackley, M.R., and William, H.R., Experimental Residence Time Distribution Measurements for Unsteady Flow in Baffled Tubes, Chem. Eng. Sci. Vol. 44 No. 7, 1989, 1471-1479.

Gierer, J., Formation and Involvement of Superoxide $\left(\mathrm{O}_{2}, / \mathrm{HO}_{2}\right)$ and Hydroxyl (OH) Radicals in TFC Bleaching Processes, Holzforchung, Vol. 51 No.1, 1997, J34J46.

Harison, S.T.L., and Mackley, M.R., A Pulsatile Flow Bioreactor, Chem. Eng. Sci., Vol. 47 No.2, 1992, 490-493.

Hewgill, M.R.,. Mackley, M.R., Pandit, A.B., and Panu, S.S., Enhancement of Gas-Liquid Mass Transfer Using Oscillatory Flow in Baffled Tubes, Chem. Eng. Sci., Vol. 48 No. 4, 1993, 799-809.

Howes, T. and Mackley, M.R., Experimental Axial Dispersion for Oscillatory Flow Through a Baffled Tube, Chem. Eng. Sci., Vol. 45 No. 5, 1990, 1349-1358.

Lachenal, D., Hydrogen Peroxide as a Delignifying Agent, In Pulp Bleaching Principles and Practice, Dence, C.W. and Reeve, D.W., Eds., Tappi Press, Atlanta, 1996, 347-362. Mackley, M.R., Using Oscillatory Flow to Improve Performance, The Chemical Engineer, 1987, February, 8-20.

Mackley, M.R., Process Innovation Using Oscillatory Flow Within Baffled Tubes,
Trans. I. ChemE, Vol. 69 Part A, 1991, 197-199.

Ni, X., Zhang, Y. and Mustafa, I., An Investigation of Droplet Size and Size Distribution in Methyl-Methacrylate Suspension in a Batch Oscillatory Baffled Reactor, Chem. Eng. Sci. Vol. 53 No.16, 1998, 2903-2919.

Ni, X., Brogan, G., Struthers, A., Bennett, D.C. and Wilson, S.F., A Systematic Study of the Effect of Geometrical Parameters on Mixing Time in Oscillatory Baffled Columns, Trans. I. ChemE., Vol. 76 Part A, 1998, 635-642.

Reeve, D.W., Introduction to Principles and Practice of Pulp Bleaching, In Pulp Bleaching Principles and Practice, Dence, C.W. and Reeve, D.W., Eds., Tappi Press, Atlanta, 1996, 1-24.

Tappi, "Tappi Test Methods", Vol. 1, T236 cm-85, Tappi Press, Atlanta, 1991, p. 1-3.

Taslim and Takriff, M. S., Investigation of Mixing Time in An Oscillatory Baffled Column, Proceedings of the $15^{\text {th }}$ Symposium of Malaysian Chemical Engineers, Johore Bahru, 2001, 4-19.

Torregrossa, L.O., Effect of Mixing on Chlorine Dioxide Bleaching, Tappi Pulping Conference, Houston ,1983, 635-641.

\section{About the authors:}

Taslim received his BEng (Chem. Eng.) from Universitas Sumatera Utara, Indonesia in 1989, and his MSc (Chem. Eng.) from Institut Teknologi Bandung in 1996. He joined Universitas Sumatera Utara as a tutor in 1990 and was later appointed as a lecturer in 1996. Currently, he is a research assistant and $\mathrm{PhD}$ student at Universiti Kebangsaan Malaysia (UKM). His research focuses on the transport phenomena in oscillatory flow in a baffled column and on the development of a novel oscillatory flow reactor for pulp bleaching.

Dr. Mohd Sobri Takriff obtained his first degree in Chemical Engineering from University of Arkansas, USA in 1991. He received his MSc (Chem. Eng.) in 1993 and $\mathrm{PhD}$ (Chem. Eng.) in 1996 from the same university. Currently, he is a lecturer at the Department of Chemical and Process Engineering, UKM. His research project was funded 
by the Ministry of Science, Technology and Environment of Malaysia under the Intensification of Research in Priority Areas (IRPA), in particular, to study the Development of a Novel Chaotic Flow Reactor for Continuous Hydrogenation Reaction. Dr. Takriff and Taslim jointly won the Bronze Award for Oscillatory Pulp Bleaching Column invention at the Expo Science and Technology 2001 organized by the Ministry of Science, Technology and Environment of Malaysia. They also won the Silver Award for Oscillatory Flow Reactor at the $30^{\text {th }}$ International Exhibition of Invention, New Techniques and Products 2002, Geneva, Switzerland. 